\title{
Study on Self-assessment of Proficiency of PES in the Four English Macro Skills
}

\author{
Gang Xu \\ College of Education and Liberal Arts, Adamson University, 900 San Marcelino St., Ermita, Manila, Philippines
}

\begin{abstract}
Sports practitioners and learners who are good at English can better serve large-scale international sports events, and at the same time can better carry forward the traditional Chinese national sports spirit and promote cultural exchanges. In this paper, literature review, mathematical analysis and questionnaire surveys are applied to study self-assessment of proficiency of college PES in the four English micro skills. Results show that college PES had lower English scores in the college entrance examination, the four English micro skills at the high school stage are poor, the English proficiency of different grades of college PES is not comparable, and the English writing ability of college PES of higher grades is slightly better than that of lower grades, and both grades have not enough time to learn English. Moreover, it acquired some promotion strategies to improve present situation that provided evidence for better learning four English micro skills.
\end{abstract}

Keywords: Self-assessment, Proficiency, Physical education students, College, Four English micro skills.

\section{Introduction}

Since the reform and opening of the People's Republic of China, the economy has continued to grow at a high speed and the degree of internationalization has become higher and higher. As the most widely used international language, English has increased in importance and popularity, and it has become more and more important in our daily lives. Although every student in China is learning English from elementary school to university, the proportion of students who are proficient in listening, speaking, reading and writing of English is very low, and college students in higher education are no exception.

In the United States and other Asian countries where Chinese students are currently enrolled, speaking fluent English is the primary requirement for students to be successful in their field of study, but some students who speak English as their second language are not meeting this requirement. This problem begins to attract the researcher's attention since the number of Chinese students in the universities is increasing. When students study English in China, there is a misunderstanding: the higher the scores they got in TOEFL, GRE or GEMT, the higher the skills they have in English.

Most of the students in China choose Economics, Marketing, Accounting and Physical Education (PE) classes which require effective communication skills and presentations during the class. These students currently do not have the ability to express themselves fully and freely which causes poor performance, anxiety, and communication apprehension during presentation.

The more the fear of negative evaluations are given the less the conversations and interactions are initiated. The less the conversations and interactions are initiated, the slower the Chinese students can improve their second language speaking skills.

Studies showed that in some Chinese universities, students in PE classes have a weaker grasp of English than ordinary college students (Chen \& Wang, 2012). According to one of the strategic objectives of Document No. 40 issued by the
State Council of the Central People's Government of the People's Republic of China, it is vital to strengthen sports exchanges with the overseas, Hong Kong, Macao and Taiwan, and serve the major-country diplomacy with Chinese characteristics because of "one country, two systems". In this policy, English communication skills is very crucial. The document also included the construction of a new pattern of sports exchanges with foreign countries. Also needed are the following (State Council Statements, 2019).

- Deepen sports exchanges and cooperation with Asian countries, especially neighboring countries.

- Pragmatically promote mutually beneficial sports cooperation with developed countries in Europe and America. - Consolidate and develop friendly sports relations with African and Latin American countries.

- Guide, support and encourage sports social organizations, sports stars, mass media, sports companies, overseas Chinese, to play a role in sports activities with foreign countries.

The learning difficulties they experience are mostly influenced by their prior exposure to Chinese teaching and learning styles. The study suggests that teachers should be aware of learners' needs and prior learning experiences, so that they could engage in more effective interventions, and assist learners in developing their own learning strategies in the academic adaptation.

According to the current level of English proficiency of college physical education students (PES) in China and the analysis of relevant professionals, college PES are not very optimistic about their interest in English learning, which is in contradiction to the strategic goals proposed by the previous country (Tian, Wang \& Han, 2018).

As far as English learning is concerned, college PES are undoubtedly a special learning group. When they enter, their cultural knowledge scores are lower than those of ordinary colleges and universities. A large amount of physical training takes up most of their time, so they have no time to consider culture class learning ( $\mathrm{Lu}, 2007)$. The general English foundation is poor, and the results are not satisfactory $(\mathrm{Wu}$, 2005). This article starts from the research on the interest, 
content, channels, time and other aspects of the English learning of college PES. Under a powerful background, analyze the problems that arise in the English learning process of college PES.

\section{Related Literature}

As the official language designated internationally, English is the most widely used language in the world, and it is also an essential language in many international organizations and conferences. After the first and second industrial revolutions, the United Kingdom and the United States have successively become world powers. These two countries have great influence in business and academic areas. They have outstanding contributions and leading positions in science and technology. Many people speak English as a second language. English is also of great significance to PE majors.

English is one of the necessary conditions for the successful graduation of college students in this major. College English courses are compulsory courses for students of this major during their schooling. Only with qualified grades and sufficient credits can they graduate successfully; For graduates who are looking for jobs, English proficiency has become one of the criteria for employers to select talents; For students who are in advanced studies and aspire to scientific research, English can help these students read advanced foreign scientific research literature. The frontier knowledge and scientific research literature of sports disciplines are written and published in English. A good command of English is of great significance for learning advanced foreign sports science theories and providing students with scientific and cutting-edge theoretical basis for writing papers. Finally, if professional Chinese sports talents can speak, read, write and speak English as fluently as NBA basketball superstar Yao Ming, China will have more sports professionals going to countries all over the world for international exchanges, and the sports industry and Chinese people's sports quality will also be greatly improved.

Under the background of economic globalization, Chinese universities are facilitating their internationalization processes. It observes that English learning is imperative for Chinese higher education system, in light of the trend that English has become a global language (Yang, 2001).

Moreover, it mentioned that one of the features is internationalizing higher education curricula and faculty (Hayhoe \& Zha, 2004). However, according to the English proficiency index report, mainland China is still ranked 47th, with a score of 49.41, far behind Japan, South Korea and Hong Kong, etc (EF, 2015). It identifies the gap between the industry demand for international talents and Chinese university students' inadequate English communicative competence (Cai, 2015).

In particular, college PES in PE have poor English foundation, weak foundation, and lack of information to learn English because of their specialty (Xu \& Tian, 2012).

It pointed out that the scores of the vocabulary part of the comprehensive listening test of PES are lower than the scores of similar tests of other majors; The knowledge of PES is relatively narrow (Wang, 2002). The PES in PE generally have poor English learning foundation and low English proficiency. Most students can fully realize the importance of English learning. However, there is insufficient information on English learning performance (Xie, Peng \& Ling, 2007).

The mastery and understanding of English vocabulary for college PES are not satisfactory, and they need to use teaching methods scientifically (Zhu, 2012). General higher education in the underdeveloped areas of northwest China needs to regularly optimize the language proficiency of college PES (Ran, 2020). The English classes for college PES are not able to fully extract the characteristics of PE, and they are difficult to learn (Li \& Chen, 2020). The individual differences of PES lead to different degrees of anxiety; Teacher-student interaction and social and cultural factors are one of the reasons for students' anxiety (Hou, 2011). Therefore, if college PES want to learn English well, they need to adjust from all aspects. The research has important theoretical and practical significance.

In the context of achieving this national strategic goal, China urgently needs to train more international sports talents (Yan, 2017). As the main target of training, college PES not only need to learn sports-related knowledge, but also need to be proficient with English language.

At present, the public English courses offered by our school are mainly based on the teaching of basic English. Classroom teaching is mainly organized according to the content of the English application ability level test, with emphasis on vocabulary and grammar. The Spoken English skills competition mainly examines the contestants' daily English communication skills and foreign-related business skills. The content involves industry business development or social and economic hot issues. The teaching content of the current English course is not suitable for the assessment content of the oral skills competition, and insufficient attention is paid to the cultivation of students' English skills application ability. The knowledge learned in the classroom cannot be effectively transformed in the competition, resulting in contestants with excellent English scores at school poor performance in the competition and no satisfactory results (Liu, 2020).

First of all, students' learning strategies can be learned or improved through training. In the process of college English learning for college students, due to insufficient cognitive strategies for college English learning, the effect of autonomous learning is not obvious enough. In the process of college English learning, educators must guide students to improve their cognitive level, improve their abilities in listening, speaking, reading and writing, and create an environment and atmosphere for online communication. Through the online voice mode, students' oral language can be trained, allowing students to engage in activities such as oral solitaire and question matching, and continuously improve their oral training; in terms of writing, guide students to construct precise learning ideas and use verbs and conjunctions reasonably and prepositions, etc., to ensure that the main article is more logically logical and more accurate in grammatical performance. Self-learning through the Internet at home is not a lonely learning for students. It also needs to be completed under the supervision and guidance of students, and to strengthen mutual communication and writing. Use 
modern network platforms to strengthen communication and exchanges between teachers and students, use good communication strategies to realize the sharing of resources and information between students and teachers. In the later stage of independent learning, students can communicate with peers or students online for some complicated problems that cannot be solved independently, plus, seek help in the entire platform, so that group members can write and brainstorm with each other and then find the best solutions (Yue, 2020).

\section{Materials and Methods}

\subsection{Research Design}

This study used descriptive research which is fact-finding with interpretation. It utilizes the gathering of data concerning the current state of things investigations through distribution of checklist. It also involves the collection of data in order to test hypothesis or to answer questions concerning the current status of the subject of the study. This conducted in the School of PE, Chengdu University, which is located in Chengdu city, Sichuan Province, China. The number of students in various majors at Chengdu University is around 20,000, with students from all over the country. Among them, the total number of School of PE is about 1,000, and they also come from all over the country.

There are about 250 students in each grade from freshman to senior. As juniors and seniors will no longer have English courses, this study will exclude them.

The English proficiency level of students in the freshman year is the highest, because they have just passed the college entrance examination and entered the university, they still remember the English knowledge they learned more clearly, and they will also take a lot of English classes in the freshman year. Although the sophomores have a small amount of English classes. Most of the PES do not like to learn English, so their English proficiency is seriously reduced, and they completely forget it by the third and fourth years. This is also based on how frequent they use English, particularly the four English micro skills of listening, speaking, reading, and writing.

Therefore, this study takes freshmen and sophomore students majoring in $\mathrm{PE}$ as the research object, which is more representative of the of PES.

\subsection{Population and Sampling Technique}

This study used percentage sampling method to choose the students in the School of PE. The researcher selected $30 \%$ of the total 250 freshmen and 250 sophomore students. There will be a total of 150 respondents, 75 freshmen PES and 75 sophomore PES.

\subsection{Questionnaire Technique}

The main instrument used by the researcher was the researcher-made questionnaire. The researcher gathered the items in the questionnaire from his readings of the different literature and studies available. It was subjected to validation by three experts.

The questionnaire has 2 main parts. The first part is on the profile of the student respondents which include their age, sex, year level and score in the college entrance examination. The second part is on the self-assessment of the proficiency of PES in four English micro skills of listening, speaking, reading, and writing.

\subsection{Data Gathering Procedure}

A letter requesting permission to conduct the study was sent to the Dean of the School of PE. When permission was granted, the researcher asked the respondents to formalize their consent to be part of the research by answering the questionnaire.

The researcher then administered the questionnaire to 150 selected students of PE in the said school.

\subsection{Statistical Treatment of Data}

For ease of the analysis of the data gathered, the researcher employed the following statistical tools and treatments for the analysis of the data:

\subsubsection{Frequency Count and Percentage.}

The researcher used these to measure the profile variables in the study.

\subsubsection{Weighted Mean.}

This was used by the researcher in the analysis of data based on the respondents' answers in the study.

\subsubsection{Standard Deviation.}

This was employed in every item that required the mean values to determine the measures of dispersion of the responses given by the respondents.

The researcher used the following Likert scale:

\begin{tabular}{ccc}
\hline Scale & Verbal Analysis & Interpretation \\
\hline $3.51-4.00$ & Strongly Agree & Highly Proficient \\
\hline $2.51-3.50$ & Agree & Proficient \\
\hline $1.51-2.50$ & Disagree & Low Proficient \\
\hline $1.00-1.50$ & Strongly Disagree & Not Proficient \\
\hline
\end{tabular}

3.5.4 T-test or ANOVA.

This parametric test was used by the researcher in testing the significant differences in the self-assessment of the respondents if year level is taken as test factor.

ANOVA This parametric test was used by the researcher in testing the significant differences in the self-assessment of the respondents if the grades in the college entrance examination is taken as a test factor.

\subsubsection{Decision Criteria.}

The analysis of the hypotheses was carried out using the 0.05 level of significance. 


\section{Results}

This part presents the results of the gathered data with the analysis and interpretation according to the statement of the problem. The profile of the students and their self-assessment on their proficiency on the four English macro skills are presented.

\section{Profile of the Respondents}

Tables 1-2 present the profile of the student respondents, all of them which are PE majors of Chengdu University, Sichuan Province, China in terms of year level and score in the College Entrance Examination.

\section{On Year Level}

Table1: Frequency Distribution of Respondents' Profile in Terms of Year Level

\begin{tabular}{ccc}
\hline Year & Frequency & Percentage \\
\hline Freshman & 77 & $51.33 \%$ \\
\hline Sophomore & 73 & $48.67 \%$ \\
\hline Total & 150 & $100 \%$ \\
\hline
\end{tabular}

As shown in Table 1, seventy-seven (77) or about $51.3 \%$ are freshman students while seventy-three (73) or $48.7 \%$ are sophomore students. The data shows that the number of freshman and sophomore student participants in this study is basically equal, and the number of freshmen is slightly larger than the number of sophomore participants. From here, it can be seen that the freshmen are more interested in researching new things.

Table 2: Frequency Distribution of Respondents' Profile in Terms of Score in College Entrance Examination

\begin{tabular}{ccc} 
Terms of Score in College Entrance Examination \\
\hline Score & Frequency & Percentage \\
\hline $0-30$ & 15 & $10 \%$ \\
\hline $30-60$ & 110 & $73.33 \%$ \\
\hline $60-90$ & 19 & $12.67 \%$ \\
\hline $90-$ above & 6 & $4.0 \%$ \\
\hline Total & 150 & $100 \%$ \\
\hline
\end{tabular}

As shown in table 2, one hundred ten students (110) or $73.3 \%$ belongs to the 30-60 bracket in their score in College Entrance Examination. It only shows that majority of the students are in the lowest bracket in their entrance exam. However, only six (6) or $4 \%$ of the student belong to the highest bracket of 90 and above. Hence, fifteen (15) or $10 \%$ of the students belongs to 0-30 bracket in their score in College Entrance Examination. Nineteen (19) or $12.7 \%$ of the students belongs to $60-90$ bracket. It can be analyzed that most of the students' scores are failing, especially in the 30-60 bracket students group. It reflects that many participants have poor English skills and writing skills in their high school years, which is also related to their lack of learning time.

In the University Entrance Examination system for PES in China, the examination is divided into two parts, one is the college entrance examination, and the other is the physical examination. All students majoring in PE studied both types of examinations at the same time in high school. They would take up $1 / 5$ of their time to train their bodies every day, which led to the dispersal of the time for learning English and not enough time to learn English. The reasons for poor abilities in various aspects including English foundation. A small number of participants have English scores of 90 or above, which is at the same level as those of students who only study English and other subjects. It shows that some students can do both types of study well, taking into account both English study and physical training. Maybe they have completed the two types of study by some special, efficient and time-appropriate methods. Just like the sports training team of Adamson University Graduate School, these training players study during the day and train at night, and finally achieved good academic and competition achievements. It is suggested here that college students majoring in PE in China must find a good learning method in high school to improve their English proficiency.

Student respondents' self-assessment on proficiency in the four English macro skills in English. Tables 3-6 shows the self-assessment of the student respondents on their proficiency in the four English macro skills.

\section{On Listening Skills}

Table 3: Student Respondents' Self-Assessment on Listening Skills

\begin{tabular}{ccc}
\hline Listening Skills & Mean & $\begin{array}{c}\text { Interpretatio } \\
n\end{array}$ \\
\hline $\begin{array}{c}\text { Pays attention well when listening with others in } \\
\text { quiet conditions during meetings and classes }\end{array}$ & 3.23 & True of Me \\
\hline $\begin{array}{c}\text { Has no problems hearing English words } \\
\text { accurately when paying attention in class. }\end{array}$ & 3.05 & True of Me \\
\hline $\begin{array}{c}\text { Takes the time to listen more carefully and } \\
\text { accurately to important information. }\end{array}$ & 2.89 & True of Me \\
\hline $\begin{array}{c}\text { Always understand spoken instruction given by } \\
\text { my teachers. }\end{array}$ & 2.86 & True of Me \\
\hline $\begin{array}{c}\text { Can listen accurately without visual aides (not } \\
\text { seeing a speaker's face, gestures, and pictures) }\end{array}$ & 3.49 & True of Me \\
\hline $\begin{array}{c}\text { Can explain things fairly well during } \\
\text { conversation in class }\end{array}$ & 3.28 & True of Me \\
\hline $\begin{array}{c}\text { Hears words clearly when a speaker's back is } \\
\text { turned or is spoken to from behind }\end{array}$ & 3.21 & True of Me \\
\hline $\begin{array}{c}\text { Pays attention to details during teacher's lecture }- \\
\text { avoids careless errors when doing school } \\
\text { activities. }\end{array}$ & 3.07 & True of Me \\
\hline $\begin{array}{c}\text { Can follow more complicated spoken directions } \\
\text { with steps or sequences. }\end{array}$ & 3.13 & True of Me \\
\hline $\begin{array}{c}\text { Listen accurately on the telephone without } \\
\text { needing things to be repeated }\end{array}$ & 3.58 & Very True of \\
Me
\end{tabular}

Legend: 3.51-4.00 Very True of me; 2.51-3.50 True of me; 1.51-2.50 Slightly true of me; $1.00-1.50$ Not true of me

It can be seen from Table 3 that the answers collected from the 10 questions listed are basically 2.51-3.50 True of me, and the Composite Mean of the 10 questions answers is in the 2.51-3.50 True of me period, of which question 10. Listen accurately the answer on the telephone without needing things to be repeated has the largest Mean value, indicating that this question is the most difficult one among the 10 questions. It can also be seen that most of the participants have poor hearing, which shows that retelling English on the phone is also the most difficult problem. Sports majors all need to do a lot of repeated training of English listening.

Among them, always understand spoken instruction given by my teachers received the lowest Mean value, indicating that participants are more involved and can follow the teacher's rhythm to understand a lot of English-related instructions. However, most English teachers in China are not native 
English speakers. If some students do not understand English in class, the teachers will use Chinese to guide the students to study better.

As for other learning environment and situational problems related to listening problems, almost all participants exist, so college students majoring in PE need to work hard to overcome related English listening problems.

\section{On Speaking Skills}

Table 4: Student Respondents' Self-Assessment on Speaking Skills

\begin{tabular}{ccc}
\hline $\begin{array}{c}\text { Speaking Skills } \\
\text { Practices using new words or expressions while } \\
\text { speaking }\end{array}$ & 3.05 & True of Me \\
\hline $\begin{array}{c}\text { Tries to learn English while watching } \\
\text { TV/Videos }\end{array}$ & 2.95 & True of Me \\
\hline $\begin{array}{c}\text { Practices English by speaking with others } \\
\text { teachers }\end{array}$ & 3.11 & True of Me \\
\hline $\begin{array}{c}\text { Discusses learning orally with classmates and } \\
\text { teation }\end{array}$ & 2.99 & True of Me \\
\hline $\begin{array}{c}\text { Practices ways to check whether the listeners } \\
\text { understood what I am saying }\end{array}$ & 3.25 & True of Me \\
\hline $\begin{array}{c}\text { While speaking, I correct when I notice that I } \\
\text { made a mistake in pronunciation }\end{array}$ & 2.99 & $\begin{array}{c}\text { True of Me } \\
\text { True of Me }\end{array}$ \\
\hline $\begin{array}{c}\text { Pays attention to similarities and differences } \\
\text { between English and my first language }\end{array}$ & 3.35 & True of Me \\
\hline I ask someone to help me improve my speaking & 3.34 & True of Me \\
\hline $\begin{array}{c}\text { Practices ways to repeat what I said in other } \\
\text { words }\end{array}$ & 3.0 & True of Me \\
\hline $\begin{array}{c}\text { 10.Pays attention to pronunciation to } \\
\text { pronounce words better }\end{array}$ & 3.1 & True of Me \\
\hline Composite Mean & 3.11 & True of Me \\
\hline
\end{tabular}

Legend: 3.51-4.00 Very True of me; 2.51-3.50 True of me; 1.51-2.50 Slightly true of me; $1.00-1.50$ Not true of me

From Table 4, we can see that the Composite Mean of the participants is in the range of 2.51-3.50 True of me. The participants are studying hard in spoken English. All the content in Table 4 is very serious by the participants. In progress. Participants have the lowest Mean value through "Tries to learn English while watching TV/Videos", indicating that participants still do not like to learn English through TV compared to other content, which is enough to show that the content of new media is more attractive to college students.

The highest Mean value of "Pays attention to similarities and differences between English and my first language" indicates that students always want to spend more time figuring out the similarities and differences between their first language and English.

From the analysis of the entire content of Table 4, spoken English is still relatively difficult for college students majoring in PE. The common problem of bad spoken English is this: After receiving the information, it is translated into Chinese in the brain-thinking in Chinese how to respond or understand what the author wants to express information-then translate the answer into English and answer in English.

In two different languages, it is impossible for all concepts to correspond one by one. The language logic difference between English and Chinese is obvious. If you simply use Chinese to understand English, it will make your understanding slower and slower. The most typical performance in reading is that you clearly understand the general meaning, but you may be completely wrong because of the differences in language logic and language thinking between Chinese and English.

Therefore, the most important thing in our spoken language learning is to be directly immersed in English learning and avoid the instinctive help provided by our mother tongue. Let English gradually become an instinct.

When we read English, reading ability and cultural background knowledge are very important. For example, when we study classical Chinese or ancient poems, we need to understand the author's life, time, allusions and other cultural background knowledge. English learning is also a principle. After nearly a thousand years of evolution in English, of course, it also has an English heritage and cultural background. This requires us not only to receive information while reading, but also to think about information. It is also very important to understand the cultural connotation of the article.

\section{On Reading Skills}

Table 5: Student Respondents' Self-Assessment on Reading Skills

\begin{tabular}{ccc}
\hline Reading Skills & Mean & Interpretation \\
\hline $\begin{array}{c}\text { Concentrates on the parts of reading materials that } \\
\text { are easy to understand }\end{array}$ & 2.85 & True of Me \\
\hline $\begin{array}{c}\text { Reads the given text twice or thrice } \\
\text { After reading s particular text, discusses its content } \\
\text { with others }\end{array}$ & 2.84 & True of Me \\
\hline $\begin{array}{c}\text { Underlines important parts of the text while } \\
\text { reading }\end{array}$ & 3.16 & True of Me \\
\hline $\begin{array}{c}\text { Tries to summarize the text in own words after } \\
\text { reading }\end{array}$ & 3.31 & True of Me $\mathrm{Me}$ \\
\hline $\begin{array}{c}\text { Reads the text aloud with another person } \\
\text { Brings dictionary or thesaurus while reading an } \\
\text { assigned text }\end{array}$ & 2.91 & True of Me \\
\hline $\begin{array}{c}\text { Use the English terms or words you know to } \\
\text { understand what you are reading }\end{array}$ & 3.13 & True of Me \\
\hline $\begin{array}{c}\text { Lists down difficult words encountered while } \\
\text { reading }\end{array}$ & 2.91 & True of Me \\
\hline $\begin{array}{c}\text { Ask a somebody to explain new words found in the } \\
\text { text while reading }\end{array}$ & 3.09 & True of Me \\
\hline Composite Mean & 3.02 & True of Me \\
\hline
\end{tabular}

Legend: 3.51-4.00 Very True of me; 2.51-3.50 True of me; 1.51-2.50 Slightly true of me; $1.00-1.50$ Not true of me

It can be seen from Table 5 that the participants' interest in English reading is very high, because they showed a good attitude towards each item in the table. Among them, Composite Mean is between 2.51-3.50 True of me, the Mean value of "Reads the given text twice or thrice" is the lowest at 2.85 , and the Mean value of "Tries to summarize the text in own words after reading" is the highest at 3.31. The data shows that the participants in this study have weak reading ability, low vocabulary storage, and cannot well understand the essential content of the English language.

Sometimes, among the multiple meanings of a word, the uncommon meanings always create obstacles to our reading. For example, when take off + clothes and hats, it means to take off, but once it is placed with the plane, take off becomes the meaning of taking off. For example: 1) shape, 2) figure, 3) number, 4) figure out. I can't figure out why he quit his job. The four meanings of figure will vary according to different contexts. 
If you find that a word is ambiguous when you read it, then it will probably have a different meaning than it usually does.

There are still many Chinese college students who should have this kind of experience. They all know the words, but they just don't know what the sentence means. There is a possibility for this: the grammatical foundation is not solid. In English, in order to express the need, the author adds many subsidiary components (including non-predicate form) to the main sentence, coordinating components, and uses a large number of clauses. Clause includes coordinating relationship, master-subordinate relationship and the combination of the two-coordinating has master-subordinate relationship, master-subordinate relationship has coordinating relationship (complex clause structure).

This also means that in English reading, we will encounter a large number of clauses, the use of non-predicate verbs, tenses, multiple sentence structures, etc., all of which are entangled and mixed together. If you have a weak grammar foundation, it's only natural to be dizzy when you see these.

Therefore, one of the foundations of reading ability must have a solid grammatical foundation.

Of course, many people lack their reading comprehension skills. Even in Chinese we can't understand the main point of the article well, so in reading and learning, we must develop a kind of thinking: we not only accept and understand information, but also need to understand the logic and culture behind the article and literary work. Background and relevant knowledge.

On Writing Skills

Table 6: Student Respondents' Self-Assessment on Writing Skills

\begin{tabular}{|c|c|c|}
\hline Writing Skills & Mean & Interpretation \\
\hline Often writes in the English language & 3.13 & True of Me \\
\hline $\begin{array}{l}\text { Uses an English grammar book while doing } \\
\text { writing activities }\end{array}$ & 3.27 & True of Me \\
\hline Uses the English words I know in different ways & 3.19 & True of Me \\
\hline $\begin{array}{l}\text { Tries to write in a comfortable and quiet place } \\
\text { where I can concentrate while writing }\end{array}$ & 3.21 & True of Me \\
\hline $\begin{array}{l}\text { Writes the draft in my native language then } \\
\text { translate it to English }\end{array}$ & 3.29 & True of Me \\
\hline $\begin{array}{l}\text { Goes back to my writing to revise the content and } \\
\text { make my ideas clearer }\end{array}$ & 2.95 & True of Me \\
\hline $\begin{array}{l}\text { Reads the feedback from my previous writing and } \\
\text { use this feedback in my next writing }\end{array}$ & 3.28 & True of Me \\
\hline $\begin{array}{l}\text { Tries to find out ways on how to be better learner } \\
\text { of English }\end{array}$ & 3.11 & True of Me \\
\hline $\begin{array}{l}\text { Records the types of errors I made so that I do not } \\
\text { keep committing such errors }\end{array}$ & 3.27 & True of Me \\
\hline $\begin{array}{l}\text { 10.Use the feedback to help me with my other } \\
\text { English skills - listening, speaking and reading }\end{array}$ & 2.94 & True of Me \\
\hline Composite Mean & 3.16 & True of Me \\
\hline
\end{tabular}

Legend: 3.51-4.00 Very True of me; 2.51-3.50 True of me; 1.51-2.50 Slightly true of me; 1.00-1.50 Not true of me.

It can be seen from Table 6 that the Composite Mean of the 10 items in the table is 3.16, which is between 2.51-3.50 True of me, which proves that the learning methods and methods in the participant table are frequently used by participants. The mean of "Writes the draft in my native language then translate it to English" is 3.29, the highest value in the table, and the mean of "Use the feedback to help me with my other English skills-listening, speaking and reading" is in the table the lowest, indicating that participants have low abilities in all aspects of English writing. Perhaps the interference of the native language thinking mode is an important factor causing the writing difficulties of college students. Language is the product of the combination of culture and society, and a form of expression of the unique way of thinking of living in a specific environment. English and Chinese languages are very different in terms of thought and expression. People who are accustomed to thinking in Chinese, if they write English articles according to their unique thinking, often involuntarily organize sentences and paragraphs in their native language. The result is unimaginable. However, it is not uncommon to see such examples of interference from mother tongue in real English writing.

Many times when college students learn English words, they only pay attention to the superficial meaning, and they don't know the potential meaning of the word, especially the different semantics of the same word in different contexts. Vocabulary is obviously lacking, and it is often difficult to find suitable words in writing to interpret the article. Only use some monotonous to make simple words modify. In addition, the general college students are also poorly trained in English tenses, voice and sentence structure. The type is single and non-authentic, with repetitive wording, un-smooth textual connection, and unable to integrate the knowledge that has been mastered.

Table 7: Summary Table of the Self-Assessment of the Respondents on their Proficiency in the Four English Micro Skills

\begin{tabular}{ccc} 
& Composite Mean & Interpretation \\
\hline Four Macro Skills & 3.17 & True of Me \\
\hline Listening & 3.11 & True of Me \\
\hline Speaking & 3.02 & True of Me \\
\hline Reading & 3.16 & True of Me \\
\hline Writing & &
\end{tabular}

Differences in the Self-Assessment of Student Respondents on their Proficiency in the Four-Macro Skills when they are Grouped According to Profile.

Tables 8-9 present the differences in the assessment of student respondents on their proficiency in the four English micro skills when they are grouped according to year level and score in the College Entrance Examination.

Table 8: Differences in the self-assessment of student respondents on their proficiency in the four English micro skills when they are grouped according to year level

\begin{tabular}{|c|c|c|c|c|c|c|c|}
\hline & Participants & Mean & $S D$ & $t$-value & Sig & Decision on $\mathrm{Ho}$ & Interpretation \\
\hline \multirow{2}{*}{ Listening } & Freshman & 3.1584 & 0.48919 & \multirow[b]{2}{*}{-0.550} & \multirow[b]{2}{*}{0.583} & \multirow[b]{2}{*}{ Accept Ho } & \multirow[b]{2}{*}{ Not significan } \\
\hline & Sophomore & 3.20000 & 0.43301 & & & & \\
\hline \multirow{2}{*}{ Speaking } & Freshman & 3.1000 & 0.48504 & \multirow{2}{*}{-0.337} & \multirow{2}{*}{0.737} & \multirow{2}{*}{ Accept Ho } & \multirow{2}{*}{ Not significant } \\
\hline & Sophomore & 3.1247 & 0.40613 & & & & \\
\hline \multirow{2}{*}{ Reading } & Freshman & 3.0156 & 0.45828 & \multirow{2}{*}{-0.174} & \multirow{2}{*}{0.862} & \multirow{2}{*}{ Accept Ho } & \multirow{2}{*}{ Not significan } \\
\hline & Sophomore & 3.0288 & 0.46859 & & & & \\
\hline \multirow{2}{*}{ Writing } & Freshman & 3.0740 & 0.51181 & \multirow{2}{*}{-2.460} & \multirow{2}{*}{0.015} & \multirow{2}{*}{ Reject Ho } & \multirow{2}{*}{ Significant } \\
\hline & Sophomore & 3.2589 & 0.40512 & & & & \\
\hline
\end{tabular}


Ho: There is no significant difference between the means of freshman and sophomore macro skills

Table 8 presents the differences in the self-assessment of the respondent on their proficiency in the four English micro skills when they are grouped according to year level. This only shows that there is no significant difference in the self-assessment of the student respondents on their proficiency in the four English micro skills when they are grouped according to year level, thus we accept the null hypothesis. In the study of $\mathrm{Li}, \&$ Chen, 2020, investigation and countermeasures of the current situation of college students in PE majors in English learning-A case study of the PE College of Henan University, he explained that PES from freshman to senior year generally have poor English foundation and not strong learning atmosphere. Existing English courses also have problems such as failure to reflect the characteristics of the sports major and the difficulty of learning for students. Students should pay attention to English and master the correct learning methods; teachers should also innovate, use multimedia methods to teach students at different levels, and develop an evaluation system suitable for students of the major; At the same time, speed up the reform of textbooks and curriculum settings and choose to meet the majors characteristic English teaching materials and reform of English curriculum content promote the development of students' professional ability.

Table 9: Differences in the self-assessment of student respondents on their Proficiency in the four English micro skills when they are grouped according to score in the College Entrance Examination

\begin{tabular}{|c|c|c|c|c|c|c|c|}
\hline Score & Participants & Mean & $S D$ & t-value & Sig & Decision on $\mathrm{Ho}$ & Interpretation \\
\hline \multirow[t]{2}{*}{$0-30$} & Freshman & 0.12 & 0.323 & \multirow{2}{*}{0.704} & \multirow{2}{*}{0.482} & \multirow{2}{*}{ Accept Ho } & \multirow{2}{*}{ Not Significant } \\
\hline & Sophomore & 0.08 & 0.277 & & & & \\
\hline \multirow{2}{*}{$30-60$} & Freshman & 0.71 & 0.455 & \multirow{2}{*}{-0.539} & \multirow{2}{*}{0.591} & \multirow{2}{*}{ Accept Ho } & \multirow{2}{*}{ Not Significant } \\
\hline & Sophomore & 0.75 & 0.434 & & & & \\
\hline \multirow{2}{*}{$60-90$} & Freshman & 0.13 & 0.338 & \multirow{2}{*}{0.120} & \multirow{2}{*}{0.904} & \multirow{2}{*}{ Accept Ho } & \multirow{2}{*}{ Not Significant } \\
\hline & Sophomore & 0.12 & 0.331 & & & & \\
\hline \multirow{2}{*}{90 - above } & Freshman & 0.04 & 0.195 & \multirow{2}{*}{-0.066} & \multirow{2}{*}{0.947} & \multirow{2}{*}{ Accept Ho } & \multirow{2}{*}{ Not Significant } \\
\hline & Sophomore & 0.04 & 0.200 & & & & \\
\hline
\end{tabular}

Ho: There is no significant difference between the mean scores of freshman and sophomore

Table 9 presents the differences in the self-assessment of the respondent on their proficiency in the four English micro skills when they are grouped according to their score in the college entrance examination. This result shows that there is no significant difference in the self-assessment of student respondents on their proficiency in the four English micro skills when they are grouped according to their score in the College Entrance Examination.

Based from the results of the survey, there is a homogeneity in their consensus as regards to their proficiency in the four English micro skills.

\section{Discussions}

In this study, all the participants are freshmen and sophomores majoring in PE. Most of the participants have low scores on the university entrance exams, and only a small number of participants have exceeded the pass line. It also indicates that the number of freshman and sophomore PES participants are basically equal even if the number of freshmen is slightly larger than the number of sophomore participants.

Participants in this study have poor proficiency in four English micro skills regarding their English proficiency background in high school is not well. It reflects that many participants had too more training time and less learning English time.

No significant difference in the students' self-assessment of their proficiency on the four English micro skills if their year level is taken as test factor. Sophomore PES are better writing then freshmen and it believes both of the two grades PES have no enough time to study English.

\section{Recommendations}

Encourage all college PES to pay attention to and learn English. At the same time, all PES in high school must find their own way like target training to practice university entrance examination.

For the for English macro skills, they can have more time to in-depth and study each of the 4 skills. The high school can have a policy that make more learning time to PES students and assign best teacher with effective method to improve PES.

The English proficiency almost has nothing to do with grade for PES in college. The school or teachers can encourage PES in each grade to start learning English any time. On the one hand, express the statement that it will never be late once you would like to start. On the other hand, the school leaders of college of PE can motivate the PES to take the spare time and other media way to study English.

\section{References}

[1] Chen, C., \& Wang, S. (2012). Research on English Learning Motivation of College PES in PE. Journal of Tianjin Institute of Sport (01), 88-89.

[2] State Council Statements (2019, September, 2nd). Retrieved from September 25th, 2021, from: http://www.gov.cn/zhengce/zhengceku/2019-09/02/con tent_5426485.htm

[3] Tian, H., W, Y., \& Han, Y., H. (2018). Research on ESP teaching and its effects in English majors in PE colleges. Journal of Beijing Sport University (06), 76-83.

[4] Lu, L., \& Wang, H., Y. (2007). "Sports English" curriculum construction status and suggestions. Journal of Shanghai University of Sport (06), 88-92.

[5] Wu, Y., G. (2005). Discussion on the orientation and curriculum setting of the English major of the Institute of PE. Journal of Shanghai University of Sport (05), 90-93. 
[6] Yang, R. (2001). An obstacle or a useful tool? The role of the English language in internationalizing Chinese universities. Journal of Studies in International Education, 5(4), 341-358.

[7] Hayhoe, R., \& Zha, Q. (2004). Becoming world-class: Chinese universities facing globalization and internationalization. Harvard China Review, 5(1), 87-92.

[8] EF Education First. (2015). EF English proficiency index 2015. Retrieved from www.ef.com/epi

[9] Cai, G. Z., \& Cook, G. (2015). Extensive own-language use: A case study of tertiary English language teaching in China. Classroom Discourse, 6(3), 242-266.

[10] Xu, G., C. \& Tian, H. (2012). Exploration of college English+ teaching for PES-Self-questioning English teaching guided by metacognitive theory. Journal of Beijing Sport University (07), 78-81.

[11] Wang, W., H. (2002). Analysis and countermeasures of PES' English listening comprehension obstacles. Journal of Wuhan Institute of PE (02), 147-148.

[12] Xie, Y., F., Peng, Z., C., \& Ling, B. (2007). Investigation and analysis of the status quo of English learning of PE college students. Journal of Huanggang Normal University (06), 91-94.

[13] Zhu, Y. (2012). Research on the problems and countermeasures of sports English vocabulary learning for college sports majors in Henan Province. Journal of Henan University of Science and Technology (12), 109-111.

[14] Li, H., H., \& Chen, J., M. (2020). Investigation and countermeasures on the status quo of English learning of college PESin PE: Taking the School of PE of Henan University as an example. Sichuan Sports Science (04), 129-132.

[15] Hou, Y. (2011). Research on Foreign Language Learning Anxiety of PES. Journal of Beijing Sport University (10), 65-68.

[16] Yan, H. (2017). Research on the quality composition and training of international sports talents in colleges and universities (Master's thesis, Shanghai International Studies University).

[17] Liu, T., Research on English Teaching Reform in Higher Vocational Colleges in the Background of Vocational Skills Competition, Professional Teaching, 2096-0603 (2020) 39-0044-02

[18] Yue, L., Research on the improvement of college students' English skills under the background of online autonomous learning. Metallurgical Management, 2020/9

[19] Li, H., H. \& Chen, J., M. (2020). Investigation and countermeasures on the status quo of English learning of college students majoring in PE: Taking the School of PE of Henan University as an example. Sichuan Sports Science (04), 129-132. 